Rio de Janeiro. Ano 13. Volume 20. Número 3. Setembro a Dezembro de 2019

Periódico Quadrimestral da Pós-Graduação Stricto Sensu em Direito Processual da UERJ

Patrono: José Carlos Barbosa Moreira (in mem.). ISSN 1982-7636. pp. 451-481

www.redp.uerj.br

\title{
RENÚNCIA A DIREITOS FUNDAMENTAIS POR MEIO DE NEGÓCIO PROCESSUAL ${ }^{1}$
}

\section{WAIVER OF FUNDAMENTAL RIGHTS VIA PROCEDURAL CONTRACT}

Rodrigo Bley Santos Mestrando em Direito das relações sociais pela Universidade Federal do Paraná, com orientação do Prof. Dr. Eduardo Talamini (2018-2020). Bacharel em Direito das relações sociais pela Universidade Federal do Paraná (2011-2016). Especialista em direito processual civil pelo Instituto Romeu Felipe Bacellar, Curitiba/PR (2017-2018). Advogado. Curitiba/PR. E-mail: rodrigobleysantos@gmail.com

RESUMO: O Art. 190 do CPC/2015 introduziu no direito brasileiro o inovador instituto dos negócios processuais atípicos. O trabalho pretende examinar uma sua modalidade específica: o negócio por meio do qual o sujeito renuncia aos seus direitos fundamentais processuais. Iniciar-se-á com uma discussão a respeito dos negócios processuais no direito brasileiro. Em segundo lugar, são examinados os direitos fundamentais no processo civil. Em seguida, será abordada a questão da renúncia a direitos fundamentais segundo a doutrina constitucional. Por fim, o trabalho definirá algumas linhas gerais para a compreensão dos limites à disponibilidade dos direitos fundamentais por meio de convenções processuais.

PALAVRAS-CHAVE: Direitos fundamentais; Negócios processuais; Disponibilidade; Formalismo-valorativo; Renúncia

\footnotetext{
${ }^{1}$ Artigo recebido em 08/02/2019 e aprovado em 28/08/2019.
} 
ABSTRACT: Art. 190 of the new Brazilian Code of Civil Procedure introduced in Brazilian law the innovative institute of unenumerated procedural contracts. This work intends to examine a particular category thereof: the contract through which the agent waives her fundamental procedural rights. I begin with a discussion about procedural contracts in contemporary Brazilian law. Followingly, I mention the role of fundamental rights in Brazilian civil procedure, especially considering the so-called constitutionalization of procedural law. After that I approach the question of waiver of fundamental rights in constitutional scholarship. In conclusion, I try to trace some general lines to find the necessary limits to the waiver of fundamental rights through procedural contracts.

KEY WORDS: Fundamental rights; Procedural contracts; Availability; "Evaluative formalism"; Waiver.

SUMÁRIO: 1. Introdução; 2. Negócios jurídicos processuais no CPC/2015: 3. Processo civil e direitos fundamentais; 4. Renúncia a direitos fundamentais: perspectiva do direito constitucional; 5. Renúncia negocial a direitos fundamentais processuais; 6. Conclusão. Referências.

\section{INTRODUÇÃO}

A renovação paradigmática do processo civil, especialmente desde a passagem do Código de Processo Civil de 2015, é assunto já explorado pela doutrina brasileira² ${ }^{2}$ A partir desta nova compreensão dos institutos fundamentais da disciplina, tem-se, mais intensamente do que nunca, a convicção de que deve haver uma conformação integral do direito processual com a normativa constitucional. Eis a razão pela qual um exame dos

\footnotetext{
${ }^{2}$ Por todos, v. MITIDIERO, Daniel. Bases para a construção de um processo civil cooperativo: o direito processual civil no marco teórico do formalismo-valorativo. Tese (Doutorado em Direito) - Universidade Federal do Rio Grande do Sul, Porto Alegre, 2007, p. 13-32.
} 
Revista Eletrônica de Direito Processual - REDP.

Rio de Janeiro. Ano 13. Volume 20. Número 3. Setembro a Dezembro de 2019

Periódico Quadrimestral da Pós-Graduação Stricto Sensu em Direito Processual da UERJ

Patrono: José Carlos Barbosa Moreira (in mem.). ISSN 1982-7636. pp. 451-481

www.redp.uerj.br

institutos processuais à luz das lentes do direito constitucional, especialmente em tempos de alteração legislativa, é sempre uma tarefa necessária.

O propósito deste artigo é realizar uma análise nestes moldes de um instituto inovador do novo diploma civil-processual: os negócios jurídicos processuais ${ }^{3}$. É certo que o instituto representa uma adição interessante ao arcabouço processual brasileiro, e justamente o seu ineditismo exige uma dose adicional de cautela por conta da doutrina, para evitar que "a euforia, normalmente causada pelo novo, venha a contagiar a processualística brasileira e, assim, impeli-la à defesa em prol de um sem número de negócios jurídicos processuais inválidos ou ineficazes"4.

É dizer: nenhuma análise das convenções processuais será suficiente sem uma importante consideração dos aspectos constitucionais em jogo. Perscrutar a validade de determinada convenção exige, por definição, o exame da sua compatibilidade com o ordenamento constitucional em todas as suas dimensões.

O estudo deste instituto em particular ainda carrega uma dimensão adicional de interesse: é que tanto o direito constitucional quanto o direito processual civil pertencem ao campo do direito público, domínio tradicionalmente resistente ao valor da autonomia privada. Tanto num quanto noutro campo, todavia, recentes desenvolvimentos legislativos, doutrinários e jurisprudenciais vêm revisitando o papel outrora secundário da liberdade, tanto em sua dimensão negativa quanto naquela positiva ${ }^{5}$. Cada vez mais se compreende como há, também no direito público, espaços importantes para o poder normativo individual $^{6}$, e por consequência como não se sustenta mais a cisão absoluta entre direito

\footnotetext{
3 Acerca da nomenclatura utilizada no presente trabalho, tomar-se-ão os termos "negócio jurídico processual", "negócio processual" e "convenção processual" como sinônimos, com aplicação equivalente. Acerca da discussão sobre a nomenclatura adequada ao instituto, v. CABRAL, Antonio do Passo, Convenções Processuais. Salvador: Editora JusPodivm, 2016, p. 51-58.

${ }^{4}$ JÚNIOR, Jaldemiro Rodrigues de Ataíde. Negócios jurídicos materiais e processuais - existência, validade e eficácia - campo-invariável e campos-dependentes: sobre os limites dos negócios jurídicos processuais. In: DIDIER JÚNIOR, Fredie (org.). Coleção Grandes Temas do Novo CPC - Negócios Processuais. $3^{\mathrm{a}}$ ed. Salvador: JusPodivm, 2017, p. 293

${ }^{5}$ Acerca da distinção entre liberdade negativa e positiva, além de suas consequências para o mundo do direito, cf. RUZYK, Carlos Eduardo Pianovski. Liberdade(s) e função: contribuição crítica para uma nova fundamentação da dimensão funcional do direito civil brasileiro. Tese (Doutorado em Direito), Universidade Federal do Paraná, Curitiba, p. 25-40.

${ }^{6}$ Um exemplo contemporâneo interessante é a possibilidade de pactuação de negócio processual de colaboração premiada no âmbito de ações de improbidade administrativa. DIDIER JÚNIOR, Fredie; BOMFIM, Daniela Santos. A colaboração premiada como negócio jurídico processual atípico nas demandas
} 
Revista Eletrônica de Direito Processual - REDP.

Rio de Janeiro. Ano 13. Volume 20. Número 3. Setembro a Dezembro de 2019

Periódico Quadrimestral da Pós-Graduação Stricto Sensu em Direito Processual da UERJ

Patrono: José Carlos Barbosa Moreira (in mem.). ISSN 1982-7636. pp. 451-481

www.redp.uerj.br

público e privado operada pela fórmula da summa divisio ${ }^{7}$. Não mais cabem raciocínios simplificadores da realidade contemporânea complexa do direito, que admite tanto a forte intervenção estatal no domínio privado quanto uma forte expressão de autonomia individual no domínio público ${ }^{8}$.

O presente trabalho propõe o exame de um ponto crítico desta intersecção: a renúncia a direitos fundamentais por negócio jurídico processual. Sabe-se que o instituto dos direitos fundamentais é uma realidade jurídica ancorada firmemente no campo do direito constitucional, servindo a sua tutela como um importante fundamento para toda a atuação estatal ${ }^{9}$. Por isso mesmo, a sua renúncia deliberada pelo titular deste direito é um assunto controverso, ao qual a doutrina constitucionalista também já dedicou pormenorizada atenção. O que falta ainda no debate brasileiro é uma reflexão sobre os limites e as possibilidades da renúncia a direitos fundamentais pelas convenções processuais, levando em consideração tanto a regra expressa do Art. 190 do CPC/2015, quanto aspectos mais gerais, tais como a abordagem processualista do tema dos direitos fundamentais processuais.

Num primeiro momento, o trabalho procurará expor o estado da questão dos negócios jurídicos processuais no ordenamento brasileiro, após já alguns anos de profícuo labor doutrinário. Em seguida, pretende-se compreender como o direito processual, especialmente a partir do CPC/2015, trata do tema dos direitos fundamentais. Segue uma análise da questão da renúncia a direitos fundamentais, especificamente a partir da percepção do direito constitucional sobre a matéria. Por fim, aborda-se a temática central

de improbidade administrativa. A\&C - Revista de Direito Administrativo \& Constitucional, Belo Horizonte, a. 17, n. 67, p. 105-120, jan./mar. 2017.

${ }^{7}$ FACHIN, Luiz Edson, SCHULMAN, Gabriel. Contratos, ordem econômica e princípios: um diálogo entre o direito civil e a Constituição 20 anos depois. In: SENADO FEDERAL: Estado e economia em vinte anos de mudança: sistema tributário e ordem econômica. Brasília, 2008, p. 349-379. Para uma discussão importante sobre o caráter histórico da summa divisio, cf. CASSAGNE, Juan Carlos. El nuevo constitucionalismo y las bases del orden jurídico. Revista de investigações constitucionais. Curitiba, v. 2, n. 1, jan/abr 2015, p. 176-178.

${ }^{8}$ PIRES, Eduardo; ADOLFO, Luiz Gonzaga Silva. Autonomia privada e suas limitações legais: reflexo da incidência indireta dos direitos fundamentais. Revista de Estudos Constitucionais, Hermenêutica e Teoria do Direito, v. 7, n. 2, 2015, p. 177.

${ }^{9}$ CORREIA, José Manuel Sérvulo. Os grandes traços do direito administrativo do século XXI. A\&C Revista de Direito Administrativo \& Constitucional, Belo Horizonte, a. 16, n. 63, jan./mar. 2016, p. 4950. Para uma visão cética com relação à facticidade dos direitos fundamentais no Estado brasileiro, contudo, v. SAMPAIO, José Adércio Leite. Direitos fundamentais como trufas da maioria. Revista de Estudos Constitucionais, Hermenêutica e Teoria do Direito, 7(3):226-234, setembro-dezembro 2015. 
Revista Eletrônica de Direito Processual - REDP.

Rio de Janeiro. Ano 13. Volume 20. Número 3. Setembro a Dezembro de 2019

Periódico Quadrimestral da Pós-Graduação Stricto Sensu em Direito Processual da UERJ

Patrono: José Carlos Barbosa Moreira (in mem.). ISSN 1982-7636. pp. 451-481

www.redp.uerj.br

do trabalho: a questão da renúncia a direitos fundamentais por meio de convenção processual.

\section{NEGÓCIOS PROCESSUAIS NO CPC/2015}

Uma das mais inovadoras alterações legislativas com a passagem do Código de Processo Civil em 2015 foi a instituição dos chamados negócios jurídicos processuais. Ancoradas no Art. 190 do CPC, as partes adquiriram o poder de modelar o processo de acordo com o seu próprio desígnio, dentro de limites.

Se no diploma anterior havia dúvida a respeito da possibilidade mesma da pactuação de negócios jurídicos concernentes sobre o processo ${ }^{10}$, com o novo Código restou consolidada a possibilidade inclusive da celebração de negócios atípicos.

Acima de tudo, a inovação do Art. 190 representa o mais expressivo exemplo de uma virada valorativa no processo civil. É correto afirmar que o ordenamento processual, na sua conformação atual, privilegia sobremaneira o princípio da autonomia privada dos indivíduos, até então atrofiado nesta esfera do direito ${ }^{11}$.

A nova importância dada à categoria dos negócios jurídicos processuais reflete uma tendência mundial de ressignificação da relação entre cidadão e Estado: da antiga responsabilidade paternalista, reveladora de uma imagem senhoril da autoridade pública, ao diálogo democrático, profundamente compreensivo da autonomia de indivíduos e associações privadas, do seu potencial criativo e das relevantes consequências no mundo do direito ${ }^{12}$.

${ }^{10}$ Para um apanhado das opiniões contrárias à existência de negócios processuais, cf. CUNHA, Leonardo Carneiro da. Negócios Jurídicos Processuais no Processo Civil Brasileiro. In: DIDIER JÚNIOR, Fredie (org.). Coleção Grandes Temas do Novo CPC - Negócios Processuais. Salvador: JusPodivm, 2017, p. 4650 .

${ }^{11}$ Acerca da natureza indisponível da quase totalidade das normas processuais do ordenamento anterior, dispõe Paulo Osternack Amaral: "Tal natureza indisponível implicava a quase que irrelevância da autonomia da vontade das partes quanto às regras processuais aplicáveis ao processo judicial. O Código de Processo Civil de 1973 foi concebido sob essa estrutura rígida. Nesse regime, não havia margem relevante para as partes convencionarem acerca das regras processuais aplicáveis ao seu litígio. Tampouco estava o juiz expressamente autorizado a alterá-las." AMARAL, Paulo Osternack. Provas: atipicidade, liberdade e instrumentalidade. $2^{\mathrm{a}}$ ed. São Paulo: Revista dos Tribunais, 2017, p. 141.

12 "Um processo em que se desenvolvam amplamente os negócios processuais: é mais consentâneo com a liberdade; confere ao jurisdicionado a dignidade que ele merece em um sistema que pretenda resolver os problemas das pessoas em vez de tutelá-las senhorialmente; tende a ser mais aderente à realidade e apto a 
Revista Eletrônica de Direito Processual - REDP.

Rio de Janeiro. Ano 13. Volume 20. Número 3. Setembro a Dezembro de 2019

Periódico Quadrimestral da Pós-Graduação Stricto Sensu em Direito Processual da UERJ

Patrono: José Carlos Barbosa Moreira (in mem.). ISSN 1982-7636. pp. 451-481

www.redp.uerj.br

A adição do instituto no direito brasileiro representa uma certa descontinuidade histórica com a tradição da disciplina. Com efeito, o panorama processualista brasileiro até a edição do presente Código atribuía à quase totalidade das normas processuais a qualidade de indisponível. Por aqui, imperou o ideal publicista de processo durante a maior parte do Século $\mathrm{XX}^{13}$.

Já o Código de Processo Civil de 1973, em que pesasse redação interessante do seu Art. $158^{14}$, também foi interpretado através das lentes publicistas ${ }^{15}$. Quando não simplesmente rejeitados como impossíveis ${ }^{16}$, os negócios processuais eram vistos com enorme ressalva pela maioria da doutrina.

Foi de José Carlos Barbosa Moreira o primeiro estudo verticalizado sobre os negócios processuais na doutrina brasileira ${ }^{17}$. Para o autor, em diálogo com a doutrina alemã, já estava presente a questão dos negócios processuais atípicos, que considerava serem possíveis. Uma maneira de analisar a viabilidade da figura, vista com reserva, seria a de operar a distinção entre normas cogentes e dispositivas, sendo a autonomia privada capaz de derrogar estas últimas em acordos não previstos pela lei ${ }^{18}$.

produzir resultados eficazes e adequados às necessidades de cada conflito." TALAMINI, Eduardo. Um processo para chamar de seu: nota sobre os negócios jurídicos processuais. Disponível em: $<$ http://www.migalhas.com.br/dePeso/16,MI228734,61044-

Um+processo+pra+chamar+de+seu+nota+sobre+os+negocios+juridicos>. Acesso em 01/07/2018.

${ }^{13}$ REDONDO, Bruno Garcia, Negócios processuais: necessidade de rompimento radical com o sistema do CPC/1973 para a adequada compreensão da inovação do CPC/2015, in DIDIER JÚNIOR, Fredie (org.). Coleção Grandes Temas do Novo CPC - Negócios Processuais. $3^{\mathrm{a}}$ ed. Salvador: JusPodivm, 2017, p. 392394.

${ }^{14}$ Art. 158: "Os atos das partes, consistentes em declarações unilaterais ou bilaterais de vontade, produzem imediatamente a constituição, a modificação ou a extinção de direitos processuais."

${ }^{15}$ No dizer de Paulo Osternack Amaral, tratava-se da estrutura rígida na qual se concebeu o CPC/1973: orientado sobretudo pela afirmação da indisponibilidade da quase totalidade das regras lá contidas, não sobrava espaço para a autonomia das partes. AMARAL, Paulo Osternack, op. cit., p. 141.

${ }^{16}$ Essa era a opinião, por exemplo, de doutrinadores como Cândido Dinamarco, Alexandre Freitas Câmara e Daniel Francisco Mitidiero. Para uma discussão acerca das opiniões contrárias na literatura brasileira, v. CUNHA, Leonardo Carneiro da, Negócios jurídicos processuais no processo civil brasileiro, in DIDIER JÚNIOR, Fredie (org.). Coleção Grandes Temas do Novo CPC - Negócios Processuais. $3^{\mathrm{a}}$ ed. Salvador: JusPodivm, 2017, p. 46-48.

17 BARBOSA MOREIRA, José Carlos. Convenções das partes sobre matéria processual. Revista de Processo, v. 33, 1984, p. 182-191.

18 " $\mathrm{O}$ mais difundido desses critérios é o que se baseia na distinção entre normas processuais cogentes e normas processuais dispositivas. Admitir-se-ia no âmbito destas e repelir-se-ia no daquelas a liberdade de convenção entre as partes. Não é certo, porém, que esse caminho leve a solução satisfatória em qualquer hipótese, antes de mais nada pela dificuldade que as vezes se encontra em tragar linha divisória nítida entre as duas espécies de normas." Ibidem, p. 184. 
Revista Eletrônica de Direito Processual - REDP.

Rio de Janeiro. Ano 13. Volume 20. Número 3. Setembro a Dezembro de 2019

Periódico Quadrimestral da Pós-Graduação Stricto Sensu em Direito Processual da UERJ

Patrono: José Carlos Barbosa Moreira (in mem.). ISSN 1982-7636. pp. 451-481

www.redp.uerj.br

Novo estudo de relevância sobre a figura foi produzido por Leonardo Greco em $2007^{19}$. O autor vê os negócios processuais como a retomada da importância da autonomia privada no processo civil, retomada esta não conflitante com o publicismo processual ${ }^{20}$. O trabalho também analisa algumas espécies de negócios jurídicos específicos, bem como dá uma proposta de limites para a sua admissibilidade, que seriam três: a) os limites de disponibilidade do direito material; b) a garantia da paridade de armas e c) princípios e garantias fundamentais integrantes do conceito de "ordem pública processual"21.

Os negócios jurídicos processuais compõem-se, segundo Fredie Didier Jr., de três espécies principais $^{22}$ : uma primeira diz respeito a modificações sobre o objeto litigioso do processo, como o reconhecimento da procedência do pedido. Há também negócios em cujo objeto reside o próprio processo: aqueles que visam a fazer alterações de mero procedimento $^{23}$ e, por fim, negócios que modificam as chamadas situações jurídicas processuais: o conjunto de direitos, deveres, ônus e demais figuras subjetivas atinentes à situação individual de cada parte processual. É este o negócio que permite a renúncia a determinados direitos, e o que será examinado com mais atenção no decorrer deste trabalho, quando o seu objeto diz respeito a direitos fundamentais processuais.

Em se tratando de espécie de negócios jurídicos, as convenções processuais se submetem à análise dos mesmos elementos de existência e requisitos de validade dedicados aos negócios em geral. Assim, compõe o núcleo dos acordos processuais o elemento da vontade dos agentes. Esta vontade não necessita ser declarada, admitindo-se a

\footnotetext{
${ }^{19}$ GRECO, Leonardo. Os atos de disposição processual - Primeiras reflexões. Revista Eletrônica de Direito processual. Out/Dez. $2007 . \quad$ Disponível em: publicacoes.uerj.br/index.php/redp/article/view/23657 >. Acesso em 31/07/2018.

20 "Não obstante esse poder das partes se contraponha ao poderes do juiz, não deve ser interpretado, de forma alguma, como uma tendência de privatização da relação processual, mas representa simplesmente a aceitação de que aquelas, como destinatárias da prestação jurisdicional, têm também interesse em influir na atividademeio e, em certas circunstâncias, estão mais habilitadas do que o próprio julgador a adotar decisões sobre os seus rumos e a ditar providências em harmonia com os objetivos publicísticos do processo, consistentes em assegurar a paz social e a própria manutenção da ordem pública.” Ibidem, p. 8

${ }^{21}$ Ibidem, p. 10-11.

${ }^{22}$ DIDIER JUNIOR, Curso de Direito Processual Civil: Introdução ao direito processual civil, parte geral e processo do conhecimento. 20. ed. Salvador: JusPodivm, 2017, p. 440.

${ }^{23}$ Também chamados de "negócios jurídicos processuais em sentido estrito", para Eduardo Talamini, op. cit., p. 12.
} 
Revista Eletrônica de Direito Processual - REDP.

Rio de Janeiro. Ano 13. Volume 20. Número 3. Setembro a Dezembro de 2019

Periódico Quadrimestral da Pós-Graduação Stricto Sensu em Direito Processual da UERJ

Patrono: José Carlos Barbosa Moreira (in mem.). ISSN 1982-7636. pp. 451-481

www.redp.uerj.br

formação de negócios processuais mediante a figura mais geral da manifestação de vontade $^{24}$.

Aspecto relevante da vontade inserta do núcleo dos acordos é o seu conteúdo: em primeiro lugar, esta vontade precisa se configurar "como exercício do poder do autorregramento da vontade, entendido como poder de escolha da categoria jurídica ou das situações jurídicas que configurarão sua eficácia" ${ }^{25}$.

Os negócios processuais também variam conforme a quantidade dos seus agentes celebrantes. Estes podem ser apenas um nos negócios unilaterais, dois nos negócios bilaterais, ou mais de dois nos negócios plurilaterais ${ }^{26}$. Quanto ao tempo dos negócios processuais, estes podem ser celebrados tanto antes quanto durante o processo. Esta leitura se infere diretamente da redação expressa do Art. $190^{27}$.

O lugar do negócio jurídico processual é aquele em que ele foi celebrado. É dado relevante por duas razões: para a observância dos "usos do lugar da celebração" e para a definição do direito material aplicável ao negócio processual ${ }^{28}$. Quanto à forma, segundo Flávio Yarshell esta deve ser necessariamente escrita, sob pena de inexistência do acordo. É assim porque o processo seria uma realidade essencialmente documental ${ }^{29}$, devendo o negócio a ela se submeter para ingressar no mundo processual.

Em se tratando de negócios jurídicos, é necessário também o escrutínio do plano da validade da convenção processual. Como se sabe, o plano da validade se considera quando o fato jurídico já existe e é "daqueles em que a vontade humana constitui elemento nuclear do suporte fático (ato jurídico stricto sensu e negócio jurídico)" ${ }^{30}$. No caso concreto, o

\footnotetext{
${ }^{24}$ NOGUEIRA, Pedro Henrique. Negócios jurídicos processuais. Salvador: JusPodivm, 2016, p 176-77.

${ }^{25}$ Ibidem, p. 180

${ }^{26}$ FARIA, Guilherme Henrique Lage. Negócios processuais no modelo constitucional de processo. Salvador: JusPodivm, 2016., p. 70-72.

${ }^{27}$ Art. 190: "Versando o processo sobre direitos que admitam autocomposição, é lícito às partes plenamente capazes estipular mudanças no procedimento para ajustá-lo às especificidades da causa e convencionar sobre os seus ônus, poderes, faculdades e deveres processuais, antes ou durante o processo.” (g.n.).

${ }^{28}$ AMARAL, Paulo Osternack. Op. cit., p. 150.

${ }^{29}$ YARSHELL, Flávio Luiz. Convenção das partes em matéria processual: rumo a uma nova era? In: DIDIER JÚNIOR, Fredie (org.). Coleção Grandes Temas do Novo CPC - Negócios Processuais. Salvador: JusPodivm, 2017, p. 77.

${ }^{30}$ MELLO, Marcos Bernardes de. Teoria do fato jurídico: plano da existência. $13^{a}$ ed. São Paulo: Saraiva, 2007, p. 100.
} 
Revista Eletrônica de Direito Processual - REDP.

Rio de Janeiro. Ano 13. Volume 20. Número 3. Setembro a Dezembro de 2019

Periódico Quadrimestral da Pós-Graduação Stricto Sensu em Direito Processual da UERJ

Patrono: José Carlos Barbosa Moreira (in mem.). ISSN 1982-7636. pp. 451-481

www.redp.uerj.br

exame da validade será desempenhado pelo juiz, a quem cabe recusar o cumprimento do negócio processual reputado inválido.

Há algumas situações específicas a que o juiz deve prestar particular atenção, quando do exame da validade dos negócios processuais. Em primeiro lugar, deve-se atentar para que as partes disponham de capacidade para a celebração do ato. A exigência torna-se óbvia em vista de a redação do Art. 190 exigir partes "plenamente capazes" 31 . A exigência da capacidade plena, no entanto, não elimina a possibilidade que partes incapazes, desde que devidamente representadas ou assistidas, possam celebrar acordos processuais ${ }^{32}$.

Em segundo lugar, a validade dos negócios processuais depende de que os direitos sobre os quais versa a controvérsia admitam autocomposição. Esta exigência se justifica em vista de a possibilidade de que o negócio jurídico processual seja relevante (ou até mesmo decisivo) para o deslinde material de uma particular controvérsia. Por esta razão, exige-se que a natureza destes direitos admita a autocomposição.

Necessário ressaltar que a admissibilidade de autocomposição não se confunde com a indisponibilidade material do direito. Com efeito, é possível a autocomposição em inúmeros casos nos quais se lida com direitos indisponíveis ${ }^{33}$. Nestes casos, caberá a celebração de negócios processuais ${ }^{34}$.

Além disso, controlar-se-á a validade dos negócios processuais quando constatada a incorrência em nulidade. Sempre que constatada a infringência de norma jurídica (regra ou princípio) cogente, seja ela de natureza material ou processual, constitucional ou legal, ou de algum elemento considerado de ordem pública, o negócio jurídico deverá ser considerado inválido. E a sanção para a invalidade, à ausência de outra específica, será a nulidade $^{35}$. Cabe a ressalva, contudo, de que a nulidade em si só não é suficiente para a decretação da invalidade do negócio processual. É necessária também a verificação do

\footnotetext{
${ }^{31}$ Art. 190: "Versando o processo sobre direitos que admitam autocomposição, é lícito às partes plenamente capazes estipular mudanças no procedimento para ajustá-lo às especificidades da causa e convencionar sobre os seus ônus, poderes, faculdades e deveres processuais, antes ou durante o processo." (g.n.)

${ }^{32}$ AMARAL, Paulo Osternack. Op. cit., p. 151.

33 CARAMELO, Antonio Sampaio. Critérios de arbitrabilidade dos litígios: revisitando o tema. Revista de Arbitragem e Mediação, São Paulo, n. 27, pp. 129-161, out./dez. 2010. p. 135.

${ }^{34}$ Enunciado 135 do FPPC: "A indisponibilidade do direito material não impede, por si só, a celebração de negócio jurídico processual."

35 "Sempre que há violação de norma cogente há invalidade, desde que a própria norma não preveja, especificamente, outra sanção para a sua infringência." MELLO, Marcos Bernardes de. Op. cit., p. 88.
} 
Revista Eletrônica de Direito Processual - REDP.

Rio de Janeiro. Ano 13. Volume 20. Número 3. Setembro a Dezembro de 2019

Periódico Quadrimestral da Pós-Graduação Stricto Sensu em Direito Processual da UERJ

Patrono: José Carlos Barbosa Moreira (in mem.). ISSN 1982-7636. pp. 451-481

www.redp.uerj.br

prejuízo no caso concreto $^{36}$. Ainda assim, a nulidade pode ser declarada apenas parcialmente ${ }^{37}$.

Ainda, a inserção abusiva em contrato de adesão se trata de uma das restrições específicas aos negócios jurídicos processuais, dispostas no parágrafo único do Art. 190 do $\mathrm{CPC}^{38}$. A racionalidade do dispositivo é impedir eventual lesão, facilitada pela posição naturalmente mais frágil, da parte oblata em contrato de adesão. Como nestes contratos a margem de negociação é diminuta, os aderentes frequentemente se veem de mãos atadas frente a conteúdos contratuais impostos unilateralmente pela parte policitante. Ressalte-se, todavia, que a restrição mencionada não é incondicionada: a inserção que se proíbe é aquela qualificada pela abusividade: o gravame imposto à parte aderente. A abusividade do acordo precisa ser demonstrada. Caso contrário, não resta obstáculo à higidez do negócio processual $^{39}$.

Por fim, o parágrafo único do Art. 190 também limita os negócios jurídicos processuais nos casos de "manifesta situação de vulnerabilidade". À semelhança do que ocorre nos contratos de adesão, a intenção do legislador aqui parece residir na evitação de que partes em situações jurídicas desfavoráveis se vejam impedidas de recorrer à tutela jurisdicional. A diferença é que esta hipótese não restringe a sua aplicação a uma modalidade contratual específica, mas a qualquer situação de vulnerabilidade manifesta.

\section{PROCESSO CIVIL E DIREITOS FUNDAMENTAIS}

Concluída uma breve exposição acerca dos negócios jurídicos processuais, cumpre agora explorar um pouco do tema dos direitos fundamentais no CPC/2015.

A recente codificação se insere no contexto do fenômeno da constitucionalização do direito infraconstitucional, iniciada a partir da Constituição Federal de 1988. Com

\footnotetext{
${ }^{36}$ Enunciado 16 do FPPC: “O controle dos requisitos objetivos e subjetivos de validade da convenção de procedimento deve ser conjugado com a regra segundo a qual não há invalidade do ato sem prejuízo."

${ }^{37}$ Enunciado 134 do FPPC: "Negócio jurídico processual pode ser invalidado parcialmente."

38 "Parágrafo único. De ofício ou a requerimento, o juiz controlará a validade das convenções previstas neste artigo, recusando-lhes aplicação somente nos casos de nulidade ou de inserção abusiva em contrato de adesão ou em que alguma parte se encontre em manifesta situação de vulnerabilidade."

${ }^{39}$ AMARAL, Paulo Osternack. Op. cit., p. 161.
} 
Revista Eletrônica de Direito Processual - REDP.

Rio de Janeiro. Ano 13. Volume 20. Número 3. Setembro a Dezembro de 2019

Periódico Quadrimestral da Pós-Graduação Stricto Sensu em Direito Processual da UERJ

Patrono: José Carlos Barbosa Moreira (in mem.). ISSN 1982-7636. pp. 451-481

www.redp.uerj.br

efeito, restou explicitado no próprio anteprojeto do atual diploma civil-processual que um objetivo da elaboração do novo Código seria a constitucionalização do processo ${ }^{40}$.

A codificação vem acompanhada de uma alteração paradigmática extremamente relevante no processo civil contemporâneo. Compreende-se que a ciência processual civil teve seu início a partir da afirmação científica da autonomia da disciplina, a partir do século XIX na doutrina alemã ${ }^{41}$. Após décadas de uma ciência de caráter bastante conceitualista, preocupada principalmente com a precisão formal de seus artifícios teóricos, o processo civil passou a ser compreendido como uma ferramenta para a resolução de problemas sociais, e sua efetividade analisada a partir de seus resultados práticos. É o que se convencionou chamar de fase instrumentalista, em que a centralidade da disciplina transitou da figura da ação para a da jurisdição ${ }^{42}$.

Nos últimos anos, entretanto, verificou-se a necessidade de compatibilizar o rigor teórico com uma perspectiva teleológica mais rica que aquela instrumentalista. Para além da preocupação com resultados práticos, passou-se a apreender com mais intensidade a adequação com valores, tanto éticos quanto constitucionais. Nesse momento, a centralidade da disciplina transitou uma vez mais, da jurisdição para a própria figura do processo. Mas não o processo enquanto estrutura formal e técnica, e sim como atributo essencial de um regime democrático constitucional, e como próprio direito fundamental do cidadão. À luz da perspectiva dos direitos fundamentais, o caráter instrumental do processo revela-se ainda mais crucial, na medida em que ele deve se apresentar como garantia efetiva da tutela de todos os demais direitos (fundamentais ou não), sempre quando estes não são assegurados de forma espontânea pelos sujeitos responsáveis por sua prestação ou respeito $^{43}$.

\footnotetext{
${ }^{40}$ DIAS, Ronaldo Brêtas de Carvalho. A constitucionalização do novo Código de Processo Civil. In: DIDIER JUNIOR, Fredie (org.), Coleção Grandes Temas do Novo CPC - Normas Fundamentais. Salvador, JusPodivm, 2016, p. 59.

${ }^{41}$ ATAIDE JUNIOR, Vicente de Paula. Processo civil pragmático. Tese (Doutorado em Direito). Curitiba, Universidade Federal do Paraná, 2013, p. 23-26.

${ }^{42}$ Ibidem, p. 26-34.

43 "Sob tal perspectiva, sempre que o titular de um direito deparar-se com uma situação de ofensa a seu direito material, poderá ele socorrer-se do aparelho estatal para obter a proteção jurisdicional adequada. Para tanto, justamente por vedar a utilização de qualquer forma privada de resolução judicial de conflitos, a organização estatal deverá em compensação prever todas as técnicas processuais idôneas à real satisfação dos direitos violados, de maneira a corresponder à realização da justiça privada que foi proibida ao particular, titular do direito. Significa dizer que sobre o Estado passa a recair o dever de prestar a tutela judicial efetiva
} 
Revista Eletrônica de Direito Processual - REDP.

Rio de Janeiro. Ano 13. Volume 20. Número 3. Setembro a Dezembro de 2019

Periódico Quadrimestral da Pós-Graduação Stricto Sensu em Direito Processual da UERJ

Patrono: José Carlos Barbosa Moreira (in mem.). ISSN 1982-7636. pp. 451-481

www.redp.uerj.br

Esta mais recente fase é denominada de formalismo-valorativo na doutrina brasileira. O vocábulo "valor”, segundo Hermes Zanetti Jr. e Claudio Madureira, invoca justamente a normatividade constitucional, especialmente na dimensão dos direitos fundamentais como um todo, e do próprio processo como direito fundamental em particular ${ }^{44}$. É lícito concluir, segundo esta perspectiva, que toda a estrutura processual contemporânea se encontra subordinada à consecução da finalidade de promover a tutela de direitos, especialmente os fundamentais.

Embora já houvesse consciência da necessidade da compatibilização do processo civil com a normatividade constitucional anterior à nova codificação ${ }^{45}$, o CPC/2015 afirma esta necessidade de forma explícita. Assim, o Código se inicia já com o capítulo relativo às normas fundamentais do processo civil, nos seus artigos $1^{\circ}$ a 12 . Importante mencionar, contudo, a advertência de Fredie Didier Jr., que distingue as normas fundamentais processuais dos direitos fundamentais processuais. Estes últimos teriam como fundamento normativo apenas o Art. $1^{\circ}$ do CPC/2015, além da própria Constituição. Já as normas fundamentais dos Arts. $2^{\circ}$ a 12 não possuiriam o status de norma de direito fundamental ${ }^{46}$. Apesar disso, não parece controverso afirmar que grande parcela do conteúdo substancial destes demais artigos apenas explicita garantias já presentes no Art. $5^{\circ}$ da Constituição, sendo assim instanciações legislativas concretas de direitos fundamentais.

ao direito material, ao qual corresponde o direito fundamental do cidadão à efetividade da tutela jurisdicional." HACHEM, Daniel Wunder. Tutela administrativa efetiva dos direitos fundamentais sociais: por uma implementação espontânea, integral e igualitária. Tese (Doutorado em Direito), Curitiba: Universidade Federal do Paraná, p. 277.

44 "O valor aqui referido diz respeito às normas constitucionais, aos direitos fundamentais compreendidos como "normas objetivas supremas do ordenamento jurídico", como substrato deontológico dos direitos fundamentais e da compreensão do processo como direito fundamental, ou seja, ver na forma (e na ordem) sua capacidade emancipatória e sua vinculação aos valores constitucionais como garantia de liberdade e de igualdade." MADUREIRA, Claudio, ZANETI JR., Hermes. Formalismo-valorativo e o novo processo civil. Revista de Processo, vol. 272/2017, on-line.

${ }^{45}$ Note-se que já em 2006, por exemplo, Luiz Guilherme Marinoni compreendia o processo como forma adequada de tutela jurisdicional dos direitos fundamentais a partir da dimensão da Constituição, além de sua própria fonte de legitimidade. "O processo é um procedimento, no sentido de instrumento, módulo legal ou conduto com o qual se pretende alcançar um fim, legitimar uma atividade e viabilizar uma atuação. $\mathrm{O}$ processo é o instrumento através do qual a jurisdição tutela os direitos na dimensão da Constituição. É o modulo legal que legitima a atividade jurisdicional, e, atrelado à participação, colabora para a legitimidade da decisão." MARINONI, Luiz Guilherme. Da teoria da relação jurídica processual ao processo civil no Estado Constitucional. Revista dos Tribunais, v. 852, a. 2006, on-line.

${ }^{46}$ DIDIER JR., Fredie. Curso de direito processual civil: Introdução ao direito processual civil, parte geral e processo de conhecimento. 20. ed., 2018, v. 1, p. 87. 
Revista Eletrônica de Direito Processual - REDP.

Rio de Janeiro. Ano 13. Volume 20. Número 3. Setembro a Dezembro de 2019

Periódico Quadrimestral da Pós-Graduação Stricto Sensu em Direito Processual da UERJ

Patrono: José Carlos Barbosa Moreira (in mem.). ISSN 1982-7636. pp. 451-481

www.redp.uerj.br

Do ponto de vista objetivo, os princípios processuais afirmados pelo CPC/2015 determinam o "termo e o caráter" de um processo judicial, além de fornecer orientações aos comportamentos das partes ${ }^{47}$. Não resta nenhuma dúvida acerca da força normativa dos princípios jurídicos no sistema processual, a qual vem explicitada ao longo de todo o texto normativo $^{48}$, e que lhe fornece um substrato axiológico capaz de assegurar coerência e justificação ${ }^{49}$.

Segundo Viviane Lemes da Rosa e William Soares Pugliese, as normas fundamentais processuais possuem as seguintes características ${ }^{50}$. Em primeiro lugar, elas possuem restringibilidade excepcional, revelando assim uma estrutura de princípios ao invés de regras. Em segundo lugar, as normas fundamentais devem ser compreendidas a partir de uma perspectiva de indivisibilidade, harmonização e complementariedade. Não é correto interpretar direitos fundamentais desde uma perspectiva isolada ou mutuamente conflitiva: figurando em igualdade no mesmo ordenamento, precisam ser aplicados e interpretados sempre de maneira indivisível. Qualquer aparente conflito deve ser resolvido mediante um expediente de harmonização (o que inclui a regra da ponderação de princípios), de forma a revelar sempre o caráter complementar, e não antagônico, daquelas normas. Além disso, a característica da maximização exige que se retire a maior intensidade normativa possível das normas fundamentais em cada caso. A proibição da vedação do retrocesso impede o abandono ou diminuição de direitos fundamentais uma vez já incorporados na disciplina processual. Por fim, a aplicabilidade imediata prescinde da positivação legislativa das normas fundamentais para a sua plena cogência no processo civil.

Não é o caso de analisar detidamente cada um dos direitos fundamentais processuais presentes no ordenamento constitucional brasileiro, nem sua especificação legislativa ao longo das regras processuais do Código. Para os fins do presente trabalho,

\footnotetext{
${ }^{47}$ GREGER, Reinhard. Cooperação como princípio processual. In: DIDIER JUNIOR, Fredie (org.), Coleção Grandes Temas do Novo CPC - Normas Fundamentais. Salvador, JusPodivm, 2016, p. 302.

${ }^{48}$ DIDIER JR., Fredie. Op.cit., p. 59.

49 PUGLIESE, William Soares, ROSA, Viviane Lemes da. Normas fundamentais do novo Código de Processo Civil: considerações teóricas e hipóteses de aplicação pelo exame do contraditório. Revista Iberoamericana de derecho procesal, v. 3, a. 2016, on-line.

${ }^{50}$ Idem.
} 
Revista Eletrônica de Direito Processual - REDP.

Rio de Janeiro. Ano 13. Volume 20. Número 3. Setembro a Dezembro de 2019

Periódico Quadrimestral da Pós-Graduação Stricto Sensu em Direito Processual da UERJ

Patrono: José Carlos Barbosa Moreira (in mem.). ISSN 1982-7636. pp. 451-481

www.redp.uerj.br

basta afirmar a natureza de um direito fundamental particular, a liberdade, e a sua relevância no contexto do processo civil contemporâneo.

Segundo Fredie Didier Jr., possui a liberdade proeminência também no processo civil. A própria concepção de devido processo legal não é completa sem um substrato de liberdade, de modo que uma limitação injustificada deste valor em algum ordenamento processual viria a ferir o devido processo ${ }^{51}$. A imbricação entre os direitos fundamentais à liberdade e ao devido processo legal autoriza a conclusão que a expressão processual do princípio da liberdade, o subprincípio do respeito ao autorregramento da vontade no processo $^{52}$, veicula um direito fundamental processual à liberdade. Como em qualquer caso, não se trata de direito ilimitado ou que prescinda de mediação legislativa. Mas é o suficiente para conectar as manifestações concretas de autonomia no processo a uma norma de direito fundamental, com relevantes consequências para o próprio "termo e caráter" de todo o processo civil. As manifestações processuais de caráter negocial, inclusive aquelas possibilitadas pelo Art. 190 do CPC/2015, passam, também, a adquirir relevância jusfundamental.

\section{RENÚNCIA A DIREITOS FUNDAMENTAIS: PERSPECTIVA DO DIREITO CONSTITUCIONAL}

Exposta a questão dos direitos fundamentais no processo civil, passa-se agora a examinar a problemática da renúncia a direitos fundamentais a partir do direito constitucional. Embora este tema surja na literatura constitucionalista tendo em vista situações existenciais (e não raro dramáticas), ainda assim alguns dos elementos discutidos podem ser transportados para a esfera do processo civil sem prejuízo: é o caso da tensa dinâmica entre liberdade e ordem pública. Para aprofundar o debate, pretende-se analisar os conceitos de direitos fundamentais enquanto direitos indisponíveis, em primeiro lugar. Em seguida, explora-se o significado do termo renúncia a direito fundamental. Por fim,

\footnotetext{
51 "Um processo que limite injustificadamente o exercício da liberdade não pode ser considerado um processo devido. Um processo jurisdicional hostil ao exercício da liberdade não é um processo devido, nos termos da Constituição brasileira.” DIDIER JR., Fredie. Op. cit., p. 165.

${ }^{52}$ A expressão também é de Didier Jr. Ibidem, p. 164.
} 
Revista Eletrônica de Direito Processual - REDP.

Rio de Janeiro. Ano 13. Volume 20. Número 3. Setembro a Dezembro de 2019

Periódico Quadrimestral da Pós-Graduação Stricto Sensu em Direito Processual da UERJ

Patrono: José Carlos Barbosa Moreira (in mem.). ISSN 1982-7636. pp. 451-481

www.redp.uerj.br

discutem-se alguns argumentos favoráveis e contrários à possibilidade de renúncia a estes direitos, bem como as condições necessárias para a validade do ato de renúncia.

Em visita à literatura jurídica acerca do conceito de indisponibilidade, Leticia Martel apresenta um quadro de obscuridade teórica. Embora se reconheça a qualidade de "indisponíveis" a determinadas espécies de direitos, em especial aos direitos fundamentais, não parece haver nem teoria unificadora do conceito nas diversas disciplinas, nem mesmo uma explicação coerente das hipóteses de renúncia a estes mesmos direitos. Em síntese, não parece haver compreensão sistematizada do conceito, tampouco subsídios legislativos que auxiliem a esclarecê-lo ${ }^{53}$. Apesar do grande dissenso, Martel encontra três grandes correntes na doutrina brasileira a respeito do tema. A primeira milita a favor da indisponibilidade de todos os direitos fundamentais, operando o conceito de jusfundamentalidade quase como sinônimo de indisponibilidade. Outra corrente pensa na ideia de indisponibilidade prima facie, capaz de ser relativizada no caso concreto. Uma última já defende o conceito de disponibilidade prima facie de todos os direitos fundamentais ${ }^{54}$.

Tampouco a jurisprudência registra algum consenso sobre o tema. A autora cita diversos casos de direitos considerados fundamentais aos quais os tribunais reconhecem a possibilidade de disposição, embora continuem a denominar "indisponíveis". É o caso dos direitos trabalhistas e previdenciários, frequentemente objetos de transação pelos seus titulares $^{55}$. Por outro lado, sabe-se ainda que muitos direitos fundamentais, em teoria indisponíveis, possuem expressão econômica relevante e são habitualmente comercializados pelos seus titulares. É o caso dos direitos de imagem, ou do direito à saúde quando do exercício de atividades insalubres ${ }^{56}$. A se imaginar a indisponibilidade sem nenhum matiz possível, seria difícil dar conta desta realidade.

Já o "termo renúncia a direitos fundamentais" também provoca debate para a doutrina constitucionalista. Pedro Augustin Adamy, por exemplo, concebe a renúncia como "a situação definida em lei, em que o titular do direito fundamental, expressamente,

\footnotetext{
${ }^{53}$ MARTEL, Letícia de Campos Velho. Indisponibilidade dos direitos fundamentais: conceito lacônico, consequências duvidosas. Espaço Jurídico, Joaçaba, v. 11, n. 2, jul./dez. 2010, p. 339.

${ }^{54}$ Ibidem, p. 351.

${ }^{55}$ Ibidem, p. 344.

${ }^{56}$ Ibidem, p. 356.
} 
Revista Eletrônica de Direito Processual - REDP.

Rio de Janeiro. Ano 13. Volume 20. Número 3. Setembro a Dezembro de 2019

Periódico Quadrimestral da Pós-Graduação Stricto Sensu em Direito Processual da UERJ

Patrono: José Carlos Barbosa Moreira (in mem.). ISSN 1982-7636. pp. 451-481

www.redp.uerj.br

renuncia a determinadas posições ou pretensões jurídicas garantidas pelo direito fundamental (... $)^{57}$.” Já Marcelo Schenk Duque não considera correto falar em renúncia ao direito especificamente, mas antes de se renunciar ao exercício concreto dos direitos fundamentais em algum caso. Seria constitucionalmente questionável, segundo o autor, renunciar ao direito enquanto tal, e não a algumas de suas consequências ${ }^{58}$.

Em estudo da literatura alemã, Duque encontra como principais argumentos opostos à ideia de renúncia a direitos (ou exercício de direitos) fundamentais ideias na seguinte linha. Entende-se, por exemplo, que paira sobre os direitos fundamentais o peso adicional do interesse público como garantidor da sua existência ${ }^{59}$. O interesse público daria a carga de irrenunciabilidade particular aos direitos fundamentais. Essa característica extrairia da ordem objetiva de valores normativos uma decorrência subjetiva impositiva: o dever de exercer direitos fundamentais, independentemente da vontade particular do sujeito.

Por outro lado, a parte da doutrina que vê com olhos positivos a hipótese da renúncia procura fundamentar a sua opinião não numa negação absoluta dos direitos fundamentais, mas sim no exercício concreto de pelo menos um deles, o direito à liberdade, ou então o direito de livre desenvolvimento da personalidade ${ }^{60}$. Assim, a renúncia não seria nada mais do que o resultado de uma análise compreensiva do sistema de direitos fundamentais, ao invés do exame do exercício de um direito isolado.

Para melhor compreender a interessante relação entre direitos fundamentais e liberdade individual, cabe mencionar o importante estudo de Luís Roberto Barroso a respeito do tema. Segundo o autor, são duas as dimensões fulcrais do princípio da dignidade humana. A primeira se traduz pela irredutibilidade do valor humano, o que importa na proibição da sua instrumentalização. A segunda dimensão concede ao indivíduo autonomia para a decisão a respeito de sua própria vida, com base nos seus valores e objetivos $^{61}$. A dignidade ainda se espraia para o campo das relações entre indivíduo e

\footnotetext{
${ }^{57}$ ADAMY, Pedro Augustin. Renúncia a direito fundamental. São Paulo: Malheiros, 2011, p. 58.

${ }^{58}$ DUQUE, Marcelo Schenk. Curso de Direitos Fundamentais: teoria e prática. São Paulo: RT, 2014. p. 107.

${ }^{59}$ Ibidem, p. 108.

${ }^{60}$ Ibidem, p. 109.

${ }^{61}$ BARROSO, Luís Roberto. Legitimidade da recusa de transfusão de sangue por testemunhas de Jeová. Dignidade humana, liberdade religiosa e escolhas existenciais. In: LEITE, George Salomão; SARLET, Ingo
} 
Revista Eletrônica de Direito Processual - REDP.

Rio de Janeiro. Ano 13. Volume 20. Número 3. Setembro a Dezembro de 2019

Periódico Quadrimestral da Pós-Graduação Stricto Sensu em Direito Processual da UERJ

Patrono: José Carlos Barbosa Moreira (in mem.). ISSN 1982-7636. pp. 451-481

www.redp.uerj.br

sociedade. Individualmente considerado, ao indivíduo é reservada uma garantia de autonomia privada, capaz de prover a sua autodeterminação. Já no que tange à relação entre governo e sociedade, surge o direito à autonomia pública como forma de viabilização de um autogoverno, uma democracia efetiva.

Uma dimensão essencial da dignidade humana é a autonomia individual. Segundo Barroso, ela serve de fundamento para os próprios direitos fundamentais. Ou seja, a base axiológica dos direitos fundamentais é a própria autonomia da pessoa. A autonomia se desdobra, de um lado, na capacidade de autodeterminação, do indivíduo tomado como agente moral abstrato. Por outro, ela assegura o respeito às condições para o exercício da autodeterminação: a possibilidade concreta de decisões livres, garantida através de condições existenciais mínimas sem as quais o consentimento é vazio ${ }^{62}$.

Outra visão da dignidade humana é a dignidade-como-heteronomia. Nestes casos, ela não milita em favor da liberdade de cada indivíduo, mas justamente o contrário: é um valor-limite que se põe contra a liberdade do ser agente, a favor da sua própria dignidade. A dignidade, assim, não fundamenta somente uma visão ilimitada de liberdade, mas dá sustento inclusive às suas restrições ${ }^{63}$. $\mathrm{Na}$ opinião do autor, prevalece no ordenamento constitucional brasileiro a visão da dignidade como autonomia.

Sendo os direitos fundamentais decorrentes do valor máximo da dignidade humana, aquilo que se depreender deste conceito maior também terá aplicabilidade aos elementos que seguem. Assim, ao vislumbrar na concepção de dignidade humana a perspectiva fundamental de autonomia dos seres humanos, os próprios direitos fundamentais passam a conter dentro de si um elemento de autonomia irredutível, embora não ilimitado. Com efeito, ao identificar no ordenamento constitucional brasileiro um princípio de primazia da autonomia, Barroso torna necessário examinar os direitos fundamentais também a partir destas lentes da autonomia ${ }^{64}$. Por isso, não se pode predicar

Wolfgang; CARBONELL, Miguel (Org.). Direitos, deveres e garantias fundamentais. Salvador: JusPodivm, 2011, p. 9.

${ }^{62}$ Ibidem, p. 11.

${ }^{63}$ Ibidem, p. 12.

${ }^{64}$ Ibidem, p. 28. 
Revista Eletrônica de Direito Processual - REDP.

Rio de Janeiro. Ano 13. Volume 20. Número 3. Setembro a Dezembro de 2019

Periódico Quadrimestral da Pós-Graduação Stricto Sensu em Direito Processual da UERJ

Patrono: José Carlos Barbosa Moreira (in mem.). ISSN 1982-7636. pp. 451-481

www.redp.uerj.br

dos direitos fundamentais uma característica de cogência autoritária. Fazê-lo seria contrário à própria dignidade que lhes dá fundamento ${ }^{65}$.

Marcelo Schenk Duque defende uma posição semelhante. O autor referenda a ideia de que a liberdade ocupa uma posição privilegiada na axiologia constitucional. Assim, há um elemento indispensável de autonomia individual inerente a cada direito fundamental, o que impede a interpretação segundo a qual a sua cogência seria absoluta, e a renúncia impossível ${ }^{66}$. Contudo, Duque admite haver situações em que o "interesse público fala contra a possibilidade de determinadas renúncias", embora sem especificar quais seriam as condições de manifestação desse interesse.

Também Leticia Martel concorda com o argumento segundo o qual é o valor constitucional da liberdade a garantia da possibilidade de disposição dos direitos fundamentais. É certo que a disposição envolve o enfraquecimento, a perda de uma posição jurídica privilegiada em face da contraparte da relação jurídica. De certa forma, portanto, a disposição adquire a feição da perda de um direito fundamental. Mas não se deve esquecer que a própria ação de dispor se trata de ato livre e, portanto, expressão do valor (e direito) fundamental da liberdade. É por isso que a disposição tem relação de certa forma ambígua com o patrimônio jusfundamental particular: ao mesmo tempo em que milita contra posições jusfundamentais particulares, ela constitui importante expressão de uma posição jusfundamental essencial: a liberdade de dar efeitos jurídicos à própria vontade $^{67}$

Conforme se pode depreender, há uma tendência considerável do pensamento constitucionalista a embasar a liberdade como fundamento normativo para a validade de atos de renúncia/disposição de direitos fundamentais. Sem este substrato libertário subjacente, a garantia dos direitos fundamentais acabaria por militar contra os interesses da

\footnotetext{
${ }^{65} \mathrm{E}$ se for relembrada a vocação do Estado para a tutela dos direitos fundamentais, percebe-se uma relação de necessário contato entre Estado e liberdade individual. Não há, todavia, como equacionar estes conceitos Estado, dignidade, liberdade - em termos de uma aparente harmonia. Trata-se de uma relação de constante tensão. Para uma discussão da dinâmica da liberdade e do Estado, v. PIRES, Luis Manuel Fonseca. Razões (e práticas) de Estado: os mal-estares entre a liberdade e a segurança jurídica. Revista de Investigações Constitucionais. Curitiba, v. 3, n. 3, set/dez. 2016, p. 167-189.

${ }^{66}$ DUQUE, Marcelo Schenk, op. cit., p. 110.

${ }^{67}$ MARTEL, Leticia. op. cit. p. 362.
} 
Revista Eletrônica de Direito Processual - REDP.

Rio de Janeiro. Ano 13. Volume 20. Número 3. Setembro a Dezembro de 2019

Periódico Quadrimestral da Pós-Graduação Stricto Sensu em Direito Processual da UERJ

Patrono: José Carlos Barbosa Moreira (in mem.). ISSN 1982-7636. pp. 451-481

www.redp.uerj.br

própria dignidade humana, a fonte última de todo direito fundamental ${ }^{68}$. No entanto, é compreensível que qualquer ato de renúncia que diga respeito a uma parcela tão crucial do patrimônio jurídico do titular gere uma necessidade de exame aprofundado sobre as condições e limites da renúncia.

Na concepção própria de Martel, o ato de disposição de direito fundamental significa o enfraquecimento volitivo de uma posição jurídica subjetiva jusfundamental titularizada pelo sujeito disponente. Dispor implica abrir mão de algo que é próprio de alguém: só cabe a disposição quando o direito fundamental em questão abriga uma dimensão subjetiva. É precisamente esta a dimensão enfraquecida na disposição. Por consequência da estrutura triádica de qualquer relação jurídica, a disposição de direito que enfraquece a esfera jurídica do renunciante fortalece, ao mesmo tempo, a esfera da parte contrária, concedendo-lhe a possibilidade de efetuar medida até então impossível a si mesma $^{69}$.

Ainda, só é possível falar de disposição no contexto de relações jurídicas intersubjetivas. Ao destruir um bem jurídico particular, não é possível dizer que determinada parte dispôs de seu próprio direito, se não houve a modificação de posição jurídica de outro sujeito de direito. Para Martel, disposição é necessariamente um ato intersubjetivo: em não havendo mais de um sujeito, não há de se falar em disposição.

Por fim, a disposição exige um ato de vontade manifestado pelo titular do direito, que deve necessariamente consistir em espécie de consentimento manifesto. Não se tratará de disposição em caso de ausência de uma manifestação válida de consentimento por parte do titular do direito ${ }^{70}$.

Duque também compreende que é necessário haver espaço para a renúncia, ainda que dentro de alguns limites muito bem delineados. Em primeiro lugar, deve-se ter em vista que a renúncia, ao exercício antes que ao direito simplesmente, é sempre pontual e

\footnotetext{
${ }^{68}$ No mesmo sentido se posicionam Joyceane Bezerra de Menezes e Renata Vilela Multedo: "O exercício da autonomia pela autodeterminação existencial é inexorável ao desenvolvimento da pessoa, enquanto sujeito independente, e, portanto, expressão material do princípio da dignidade da pessoa humana considerada in concreto.” MENEZES, Joyceane Bezerra de, MULTEDO, Renata Vilela. A autonomia ético-existencial do adolescente nas decisões sobre o próprio corpo e a heteronomia dos pais e do Estado no Brasil. A\&C Revista de Direito Administrativo \& Constitucional, Belo Horizonte, a. 16, n. 63, jan./mar. 2016, p. 191192.

${ }^{69}$ MARTEL, Leticia. op. cit. p. 355.

${ }^{70}$ Ibidem, p. 357.
} 
Revista Eletrônica de Direito Processual - REDP.

Rio de Janeiro. Ano 13. Volume 20. Número 3. Setembro a Dezembro de 2019

Periódico Quadrimestral da Pós-Graduação Stricto Sensu em Direito Processual da UERJ

Patrono: José Carlos Barbosa Moreira (in mem.). ISSN 1982-7636. pp. 451-481

www.redp.uerj.br

aplicável a uma situação particular, e não uma renúncia geral e abstrata ${ }^{71}$. Por outro lado, a renúncia deve ser sempre individual, porquanto não é dado a ninguém renunciar sobre direito alheio. Ainda, a interpretação a respeito da renúncia deve ser sempre estrita, e a renúncia mesma deve sempre ser reversível ${ }^{72}$. Eis a razão pela qual seria errôneo considerar a renúncia como espécie de perda de um direito. Ele nunca se perde completamente, tanto é que a possibilidade de reversão da renúncia permanece presente.

Ainda, a renúncia não poderia tocar o chamado "núcleo essencial" do direito fundamental, mas apenas as suas manifestações mais distantes deste núcleo, abertas à disponibilidade eventual. A ressalva guarda, no entanto, a dificuldade inerente de precisar em que consiste o núcleo essencial de determinado direito fundamental, assunto ao qual a doutrina constitucional já dedicou enorme atenção ${ }^{73}$.

Uma orientação valiosa que Duque apresenta para avaliar o caso difícil da proteção do Estado do particular contra a sua própria vontade consiste no exame da possibilidade de autodeterminação do particular. Tratar-se-ia, portanto, de uma análise mais substancial que a capacidade formal, mas a verificação de condições concretas de que o indivíduo necessitaria dispor para assegurar a validade do seu ato de renúncia. Assim, ao grau axiologicamente mais intenso dos direitos fundamentais corresponderia o grau mais intenso da capacidade concreta do indivíduo que renuncia. O maior peso em jogo do direito disposto seria contrabalanceado pela garantia mais forte da consciência e liberdade do indivíduo.

Especialmente no caso de uma dinâmica contratual, esta garantia de autodeterminação se faz premente. Nestes casos, o exame da desigualdade incidente numa determinada relação interprivada é essencial. Será particularmente crítica a situação de uma relação desequilibrada, na qual a parte mais débil seja (ao menos possivelmente) hipossuficiente, e na qual ela mesma seja a renunciante de um direito fundamental. Haverá

\footnotetext{
${ }^{71}$ DUQUE, Marcelo Schenk, op. cit., p. 109.

72 Ibidem, p. 115.

${ }^{73}$ Para uma discussão interessante sobre o núcleo essencial dos direitos fundamentais, v. SILVA, Virgílio Afonso da. Direitos fundamentais: conteúdo essencial, restrições e eficácia. 2. ed. São Paulo: Malheiros, 2014. p. 183-207.
} 
Revista Eletrônica de Direito Processual - REDP.

Rio de Janeiro. Ano 13. Volume 20. Número 3. Setembro a Dezembro de 2019

Periódico Quadrimestral da Pós-Graduação Stricto Sensu em Direito Processual da UERJ

Patrono: José Carlos Barbosa Moreira (in mem.). ISSN 1982-7636. pp. 451-481

www.redp.uerj.br

razões fortes para o Estado-juiz operar uma intervenção equalizadora num caso como este $^{74}$.

Compreende-se que a renúncia a exercício de direito fundamental, enquanto ato de vontade do ser humano, constitui expressão de sua liberdade individual e guarda conexão com o valor intrínseco da dignidade humana. No entanto, a renúncia encontra sua própria limitação no momento em que acaba por atentar contra a dignidade humana que lhe dá fundamento. A dificuldade reside na verificação concreta da linha tênue que distingue a liberdade a favor da dignidade, mesmo contra um direito fundamental, e a liberdade contra a dignidade, justamente por ferir o direito fundamental. A despeito disso, não há como negar que o fundamento axiológico da liberdade é a própria dignidade humana, razão pela qual a extensão da própria liberdade não pode se dar de forma ilimitada. $\mathrm{O}$ ato de vontade que "indignifica", neste sentido, perde qualquer normatividade e não merece acolhida jurídica. É o que afirma Duque: "O que se deve evitar, a todo custo, é que a pessoa, ainda que pela via de renúncia ao exercício de um direito fundamental, seja convertida em objeto ou em ferramenta da ação alheia." ${ }^{75}$.

Barroso também defende, embora brevemente, algumas condições necessárias à validade dos atos de disposição. Os elementos são três: o sujeito do consentimento, a liberdade de escolha e a decisão informada. Quanto ao primeiro, sustenta o autor que o sujeito disponente tenha capacidade civil e esteja apto a manifestar sua vontade, mediante manifestação expressa, personalíssima e inequívoca. Por outro lado, a liberdade de escolha protege o sujeito de "influências externas indevidas, como induções, pressões ou ameaças". É dizer, o ordenamento deve assegurar que o ato de disposição não seja viciado pela influência nefasta de terceiros. Por fim, é necessária a decisão informada, consubstanciada na plena "compreensão daquele que vai consentir acerca de sua situação real e das consequências da sua decisão"76.

\section{RENÚNCIA NEGOCIAL A DIREITOS FUNDAMENTAIS PROCESSUAIS}

\footnotetext{
${ }^{74}$ DUQUE, Marcelo Schenk, op. cit., p. 117.

75 Ibidem, p. 114.

${ }^{76}$ BARROSO, Luís Roberto, op. cit., p. 31-32.
} 
Revista Eletrônica de Direito Processual - REDP.

Rio de Janeiro. Ano 13. Volume 20. Número 3. Setembro a Dezembro de 2019

Periódico Quadrimestral da Pós-Graduação Stricto Sensu em Direito Processual da UERJ

Patrono: José Carlos Barbosa Moreira (in mem.). ISSN 1982-7636. pp. 451-481

www.redp.uerj.br

Feitas estas considerações, é possível traçar algumas linhas gerais para o problema da renúncia a direitos fundamentais por convenção processual.

Com base nas conclusões da seção anterior, é possível afirmar a existência de um núcleo de liberdade intrínseco a toda normatividade jusfundamental, bem como ao próprio conceito de dignidade humana ${ }^{77}$. Na medida em que o ordenamento jurídico tem como finalidade a promoção da dignidade dos indivíduos que lhes são destinatários, uma atenção especial à liberdade destes indivíduos constitui um passo metodológico inescapável. Neste sentido, os direitos fundamentais - e não há razão aparente para excluir os direitos fundamentais processuais da análise - guardam relação intrínseca com a liberdade. A relação assume dimensão crítica justamente no caso da renúncia a direito fundamental.

Tendo origem constitucional, o direito fundamental à liberdade tem por condão a sua irradiação para os domínios jurídicos infraconstitucionais, inclusive o processo civil. Mesmo o vetusto princípio do devido processo legal passa a ser lido de forma a conter também um núcleo de liberdade, que muito se coaduna com a normatividade constitucional. É evidente que a liberdade se manifestará de forma diferente de acordo com as particularidades de cada disciplina, mas não é mais - se algum dia já o foi - razoável negar um substrato necessário de liberdade para a conformação do processo civil brasileiro contemporâneo, especialmente no contexto do formalismo-valorativo.

O instituto dos negócios processuais constitui manifestação do princípio constitucional da liberdade, em sua dimensão de autonomia privada, no processo civil brasileiro. Este dado normativo deve necessariamente estar em perspectiva quando do exame do problema abordado, qual seja, a questão da renúncia a direitos fundamentais por negócios processuais. Ademais, o escopo do instituto dos negócios processuais, tal como explicitado na redação do Art. 190 do Código de Processo Civil, permite a disposição sobre os direitos das partes $^{78}$.

\footnotetext{
${ }^{77}$ Para uma análise filosófica da relação entre dignidade humana e liberdade, v. LEE, Patrick e GEORGE, Robert P., The Nature and Basis of Human Dignity, Ratio Juris, v. 21, no. 2, 2 June 2008.

78 “Art. 190. Versando o processo sobre direitos que admitam autocomposição, é lícito às partes plenamente capazes estipular mudanças no procedimento para ajustá-lo às especificidades da causa e convencionar sobre os seus ônus, poderes, faculdades e deveres processuais, antes ou durante o processo." A redação literal não menciona o termo "direitos", mas menciona o termo "deveres processuais", justamente o correlativo lógico do conceito de direito subjetivo, numa perspectiva hohfeldiana. Assim, dispor sobre deveres processuais implica logicamente poder dispor sobre direitos processuais.
} 
Revista Eletrônica de Direito Processual - REDP.

Rio de Janeiro. Ano 13. Volume 20. Número 3. Setembro a Dezembro de 2019

Periódico Quadrimestral da Pós-Graduação Stricto Sensu em Direito Processual da UERJ

Patrono: José Carlos Barbosa Moreira (in mem.). ISSN 1982-7636. pp. 451-481

www.redp.uerj.br

Isto posto, parece inquestionável que é possível a renúncia a direitos fundamentais por convenção processual ${ }^{79}$. Verifica-se que na prática a comunidade processual já aceitou ao menos algumas convenções sobre matérias atinentes a direitos fundamentais.

Um exemplo seria a convenção sobre prova. Por conta de sua relação com os princípios do contraditório (em sua dimensão substancial) e da ampla defesa, a doutrina parece convergir no sentido de considerar a prova um direito fundamental dos jurisdicionados ${ }^{80}$. Da mesma forma, alguns tratados internacionais de direitos humanos, integrantes do bloco brasileiro de constitucionalidade, consagram a prova como direito fundamental ${ }^{81}$. No entanto, o Enunciado 21 do Fórum Permanente de Processualistas Civis admite convenção sobre prova ${ }^{82}$. Paulo Osternack Amaral chega a afirmar que "o negócio processual encontra campo fértil na esfera probatória", constituindo negócios válidos, por exemplo, a admissão de uma única modalidade de produção probatória, ou a exclusão de uma modalidade específica, a vedação à participação de assistentes técnicos no processo, dentre outros ${ }^{83}$.

Todas as manifestações negociais elencadas acima constituem atos de disposição livres sobre direitos fundamentais. Na medida em que constituem atos de enfraquecimento volitivo de uma posição jurídica subjetiva jusfundamental, o sujeito que a titulariza, no momento em que abdica desta mesma posição, efetua ato de renúncia a um direito fundamental. Assim, a parte que aceita excluir determinada modalidade de produção

\footnotetext{
${ }^{79}$ De acordo com esta posição, v. CABRAL, Antonio do Passo. Op. cit., p. 172-180.

80 "O direito à prova é extraído tanto da Constituição quanto da legislação infraconstitucional. À luz da Constituição, não há dúvida de que tal direito é inferido das garantias do justo processo, assegurado pelos princípios do contraditório, da ampla defesa, traduzindo-se na "liberdade de acesso às fontes e meios segundo o disposto em lei e sem restrições que maculem o justo processo." AMARAL, Paulo Osternack. Op. cit., p. 32. No mesmo sentido DIDIER JR. Fredie, BRAGA, Paula Sarno e OLIVEIRA, Rafael Alexandria. Curso de Direito Processual Civil: Teoria da prova, direito probatório, decisão, precedente, coisa julgada e tutela provisória. 13. ed. Salvador, JusPodivm, 2018, p. 50-51.

${ }^{81}$ É o caso do art. $8^{\circ}$ da Convenção Americana de Direitos Humanos e o Art. 14.1, alínea "e", do Pacto Internacional de Direitos Civis e Políticos.

${ }^{82}$ Enunciado 21 do FPPC: "São admissíveis os seguintes negócios, dentre outros: acordo para realização de sustentação oral, acordo para ampliação do tempo de sustentação oral, julgamento antecipado do mérito convencional, convenção sobre prova, redução de prazos processuais.” (g.n.)

${ }^{83}$ AMARAL, Paulo Osternack. Op. cit., p. 156-157.
} 
Revista Eletrônica de Direito Processual - REDP.

Rio de Janeiro. Ano 13. Volume 20. Número 3. Setembro a Dezembro de 2019

Periódico Quadrimestral da Pós-Graduação Stricto Sensu em Direito Processual da UERJ

Patrono: José Carlos Barbosa Moreira (in mem.). ISSN 1982-7636. pp. 451-481

www.redp.uerj.br

probatória de seu arsenal jurídico em determinado processo vê diminuído o alcance normativo do seu direito fundamental à prova ${ }^{84}$.

Assim como a renúncia ao direito à prova, certamente posições jurídicas de caráter jusfundamental diferentes são admissíveis. Não se propõe neste momento elencar exaustivamente cada uma delas. $O$ que se sugere é que as conclusões da doutrina constitucional têm relevância para o caso dos negócios processuais de renúncia a direitos fundamentais, de forma que algumas linhas gerais podem ser traçadas.

A renúncia a direitos fundamentais tem sempre limites. No caso dos negócios processuais, não será diferente. Em primeiro lugar, toda manifestação negocial depende do componente da capacidade subjetiva do sujeito agente. Todavia, o caráter jusfundamental do direito renunciado exige que se inclua neste conceito de capacidade um conteúdo normativo um pouco mais intenso, capaz de fazer frente à relevância concedida pelo ordenamento àquela espécie de direitos. Assim, o termo "partes plenamente capazes" do Art. 190 do CPC/2015 deve conter um grau suficiente de autodeterminação do sujeito, consistente na garantia da consciência da natureza e das consequências do ato praticado, bem como a garantia de que a renúncia consista numa decisão livre. Na prática, a verificação de que a parte toma uma decisão plenamente informada ${ }^{85}$, além de livre de pressões socioeconômicas desproporcionais ${ }^{86}$, se faz necessária. Caso contrário, há a possibilidade de que a parte renunciante reste instrumentalizada pelo ato de renúncia.

\footnotetext{
${ }^{84}$ Uma possível objeção a este argumento seria a de que a convenção sobre prova que envolvesse renúncia teria caráter necessariamente bilateral, sob pena de se incorrer em uma iniquidade contrária à ordem pública processual. Assim, não haveria um ato de renúncia do qual resultasse um claro "vencedor", isto é, uma parte que visse apenas a sua posição jurídica subjetiva somente fortalecida em detrimento do arrefecimento da posição da parte contrária. Não se trataria, portanto, de renúncia a direito fundamental. Parece haver duas formas de responder à objeção: em primeiro lugar, não resta demonstrada a necessidade de bilateralidade em todos os casos de convenção processual. Em segundo lugar, a contingência da bilateralidade não desnatura o próprio ato de renúncia, no sentido de um enfraquecimento volitivo da própria posição jurídica subjetiva. A bilateralidade apenas indica que a renúncia se opera nos dois lados da relação ao mesmo tempo. As duas partes continuam a renunciar, ao mesmo tempo em que são fortalecidas pelo ato de renúncia da outra parte. Assim, a parte da relação processual que renuncia, e.g., à modalidade de prova pericial, efetivamente abre mão do direito de utilizá-la num determinado processo, a despeito do fato de que passa a titularizar o direito de que a outra parte também não a utilize.

${ }^{85}$ Os critérios mínimos de uma decisão livre e informada são seguidos pela Corte e pela Comissão Europeia de Direitos Humanos, segundo Antonio do Passo Cabral. CABRAL, Antonio do Passo. Op. cit., p. 178-179.

${ }^{86}$ O CPC/2015 parece capturar suficientemente esta última preocupação no parágrafo único do Art. 190, ao recusar a aplicação das convenções nos casos de "inserção abusiva em contrato de adesão" e em "manifesta situação de vulnerabilidade".
} 
Revista Eletrônica de Direito Processual - REDP.

Rio de Janeiro. Ano 13. Volume 20. Número 3. Setembro a Dezembro de 2019

Periódico Quadrimestral da Pós-Graduação Stricto Sensu em Direito Processual da UERJ

Patrono: José Carlos Barbosa Moreira (in mem.). ISSN 1982-7636. pp. 451-481

www.redp.uerj.br

Além disso, algumas considerações quanto ao ato de consentimento devem se fazer presentes. É importante que este seja manifesto e facilmente discernível, justamente para se assegurar plenamente do conteúdo da vontade da parte disponente. Em se tratando ainda de ato de renúncia, deve ser ele pontual e individual, além de sua interpretação ser restritiva $^{87}$. Além disso, não se pode renunciar a direito alheio, devendo o ato de renúncia atingir apenas a parte que o efetua ${ }^{88}$.

Em vista da essencial dimensão publicística do processo, o qual não se reduz à condição de "coisa das partes", uma consideração especial do interesse público do Estadojuiz deve também ser considerada quando da análise da higidez das convenções ${ }^{89}$. Com efeito, cada processo tem certa medida de relevância transcendente ao interesse das próprias partes, o que autoriza uma carga de cogência mais intensa do que em relações privadas. $\mathrm{O}$ conceito que parece traduzir da melhor forma estas considerações de interesse público é o da ordem pública processual, definido por Leonardo Greco como um conjunto de princípios fundamentais indisponíveis, "impostos de modo imperativo" para assegurar a proteção de interesse público precisamente determinado ${ }^{90}$. Alguns dos elementos da ordem pública processual incluiriam as garantias de independência, imparcialidade e competência absoluta do juiz, bem como a garantia de um processo equitativo, contraditório e público, e a necessidade de fundamentação das decisões judiciais. Renunciar a qualquer um destes direitos processuais, sem dúvida fundamentais, incorreria em nulidade por conta da violação da ordem pública processual.

Ainda, Marcelo Schenk Duque afirma que um limite último à renunciabilidade de direitos fundamentais consistiria na necessária preservação do seu núcleo essencial ${ }^{91}$. A observação parece pertinente também no caso da renúncia a direitos fundamentais processuais. Parece desarrazoada uma renúncia que dispa o titular do direito até mesmo de

${ }^{87}$ Enunciado $n^{\circ} 406$ do FPPC: "Os negócios jurídicos processuais benéficos e a renúncia a direitos processuais interpretam-se estritamente. ". Da mesma forma o Enunciado no 419 do FPPC: "É possível negócio jurídico processual que estipule mudanças no procedimento das intervenções de terceiros, observada a necessidade de anuência do terceiro quando lhe puder causar prejuízo."

${ }^{88}$ Enunciado no 42 do FPPC: “A eficácia dos negócios processuais para quem deles não fez parte depende de sua anuência, quando lhe puder causar prejuízo."

$89 \mathrm{Na}$ doutrina constitucional, por exemplo, Duque reconhece que a renunciabilidade dos direitos fundamentais pode ser obstada em algumas situações por considerações de interesse público. V. DUQUE, Marcelo Schenk. Op. cit., p 110.

${ }^{90}$ GRECO, Leonardo. Op. cit., p. 11-12.

${ }^{91}$ DUQUE, Marcelo Schenk. Op. cit., p. 111. 
Revista Eletrônica de Direito Processual - REDP.

Rio de Janeiro. Ano 13. Volume 20. Número 3. Setembro a Dezembro de 2019

Periódico Quadrimestral da Pós-Graduação Stricto Sensu em Direito Processual da UERJ

Patrono: José Carlos Barbosa Moreira (in mem.). ISSN 1982-7636. pp. 451-481

www.redp.uerj.br

um conteúdo mínimo. Antonio do Passo Cabral concorda com a afirmação, afirmando o que parece ser um conteúdo mínimo absoluto dos direitos fundamentais processuais ${ }^{92}$. Assim, convenções que extrapolem os limites do razoável a ponto de obstaculizar completamente a fruição do direito pelo agente renunciante não teriam validade. Uma convenção como o pactum de non petendo, por exemplo, não poderia obstaculizar a propositura de ação por prazo indefinido, e uma convenção de dilação de prazos processuais tampouco poderia dilatar prazos para além dos limites do razoável. Igualmente inadmissível seria uma convenção que impusesse custos desmedidos a uma das partes, seja financeiros, seja de outra natureza, a ponto de tornar o acesso à justiça inviável na prática.

Parece haver aqui uma certa sobreposição entre os conceitos de ordem pública processual e o núcleo essencial dos direitos fundamentais processuais. Se a ordem pública tem como característica "a direta e estreita vinculação aos objetivos e à razão de ser da atividade jurisdicional do Estado"93, uma aniquilação total de determinado direito fundamental processual, ainda que por renúncia voluntária, pode acabar por comprometer a própria razão de ser do mister jurisdicional. Isso explica a razão pela qual o caráter publicístico do processo dota a renúncia a direito fundamental de um caráter supraindividual. Diferentemente dos casos costumeiramente estudados pela doutrina constitucional, no âmbito processual o interesse do Estado-juiz permanece sendo uma consideração de grande relevância.

\section{CONCLUSÃO}

Neste artigo, pretendeu-se analisar a questão da renúncia a direitos fundamentais processuais por meio de negócio processual. Após uma breve exposição sobre os principais aspectos do instituto, especialmente na sua inovadora modalidade atípica, o trabalho examinou a relação entre o processo civil contemporâneo e os direitos fundamentais. Verificando a profunda fertilização do formalismo clássico pela normatividade constitucional, concluiu-se que os direitos fundamentais ocupam espaço privilegiado no

\footnotetext{
${ }^{92}$ CABRAL, Antonio do Passo. Op. cit., p. 335-340.

93 APRIGLIANO, Ricardo de Carvalho. Ordem pública e processo: o tratamento das questões de ordem pública no direito processual civil. São Paulo: Atlas, 2011, p. 105.
} 
Revista Eletrônica de Direito Processual - REDP.

Rio de Janeiro. Ano 13. Volume 20. Número 3. Setembro a Dezembro de 2019

Periódico Quadrimestral da Pós-Graduação Stricto Sensu em Direito Processual da UERJ

Patrono: José Carlos Barbosa Moreira (in mem.). ISSN 1982-7636. pp. 451-481

www.redp.uerj.br

paradigma processual contemporâneo. Após uma visita ao estado da questão da renúncia a direitos fundamentais a partir da disciplina do direito constitucional, o trabalho pretendeu responder à questão da possibilidade da sua renúncia por convenção processual. Respondese de forma afirmativa: a renúncia é claramente possível. Todavia, há uma série de requisitos de observância obrigatória para que esta renúncia se dê de modo válido. Também aqui o exame da questão do ponto de vista da doutrina constitucional foi proveitoso, uma vez que se permitiu a definição de algumas linhas gerais de aferição da renúncia. Pode-se concluir que a renúncia por convenção processual é uma espécie do gênero renúncia a direitos fundamentais, sendo aplicáveis as mesmas linhas gerais em ambos os casos. Se reside alguma particularidade no caso processual, trata-se da natureza publicística do processo, que autoriza um emprego mais intenso de conceitos como a ordem pública, para a salvaguarda dos fins da atividade jurisdicional.

\section{REFERÊNCIAS}

ADAMY, Pedro Augustin. Renúncia a direito fundamental. São Paulo: Malheiros, 2011. AMARAL, Paulo Osternack. Provas: atipicidade, liberdade e instrumentalidade. $2^{\text {a }}$ ed. São Paulo: Revista dos Tribunais, 2017.

APRIGLIANO, Ricardo de Carvalho. Ordem pública e processo: o tratamento das questões de ordem pública no direito processual civil. São Paulo: Atlas, 2011.

ATAÍDE JÚNIOR, Jaldemiro Rodrigues de. Negócios jurídicos materiais e processuais existência, validade e eficácia - campo-invariável e campos-dependentes: sobre os limites dos negócios jurídicos processuais, in: in: DIDIER JÚNIOR, Fredie (org.). Coleção Grandes Temas do Novo CPC - Negócios Processuais. $3^{\text {a }}$ ed. Salvador: JusPodivm, 2017.

ATAIDE JUNIOR, Vicente de Paula. Processo civil pragmático. Tese (Doutorado em Direito) Universidade Federal do Paraná, Curitiba, 2013, $278 \mathrm{f}$.

BARBOSA MOREIRA, José Carlos. Convenções das partes sobre matéria processual. Revista de Processo, v. 33, 1984, p. 182-191. 
BARROSO, Luís Roberto. Legitimidade da recusa de transfusão de sangue por testemunhas de Jeová. Dignidade humana, liberdade religiosa e escolhas existenciais. In: LEITE, George Salomão; SARLET, Ingo Wolfgang; CARBONELL, Miguel (Org.). Direitos, deveres e garantias fundamentais. Salvador: JusPodivm, 2011. p. 661-708.

CABRAL, Antonio do Passo. Convenções processuais. Salvador: JusPodivm, 2016.

CARAMELO, Antonio Sampaio. Critérios de arbitrabilidade dos litígios: revisitando o tema. Revista de Arbitragem e Mediação, São Paulo, n. 27, out./dez. 2010, p. 129161.

CASSAGNE, Juan Carlos. El nuevo constitucionalismo y las bases del orden jurídico.

Revista de Investigações Constitucionais. Curitiba, vol. 2, n. 1, p. 167-224, jan./abr. 2015.

CORREIA, José Manuel Sérvulo. Os grandes traços do direito administrativo do século XXI. A\&C - Revista de Direito Administrativo \& Constitucional, Belo Horizonte, a. 16, n. 63, jan./mar. 2016, p. 49-50.

CUNHA, Leonardo Carneiro da. Negócios Jurídicos Processuais no Processo Civil Brasileiro. In: DIDIER JÚNIOR, Fredie (org.). Coleção Grandes Temas do Novo CPC - Negócios Processuais. Salvador: JusPodivm, 2017, p. 39-75.

DIAS, Ronaldo Brêtas de Carvalho Dias. A constitucionalização do novo Código de Processo Civil. In: DIDIER JUNIOR, Fredie (org.), Coleção Grandes Temas do Novo CPC - Normas Fundamentais. $1^{a}$ ed. Salvador, JusPodivm, 2016, p. 59-75.

DIDIER JUNIOR, Curso de Direito Processual Civil: Introdução ao direito processual civil, parte geral e processo do conhecimento. 20. ed. Salvador: JusPodivm, 2017, . Princípio do respeito ao autorregramento da vontade no processo civil. DIDIER JR, Fredie (org.). Coleção Grandes Temas do Novo CPC - Negócios Processuais. 3. ed. Salvador: JusPodivm, 2017, p. 31-39.

DIDIER JÚNIOR, Fredie; BOMFIM, Daniela Santos. A colaboração premiada como negócio jurídico processual atípico nas demandas de improbidade administrativa. In: A\&C - Revista de Direito Administrativo \& Constitucional, Belo Horizonte, a. 17, n. 67, p. 105-120, jan./mar. 2017. 
DIDIER JR. Fredie, BRAGA, Paula Sarno e OLIVEIRA, Rafael Alexandria. Curso de Direito Processual Civil: Teoria da prova, direito probatório, decisão, precedente, coisa julgada e tutela provisória. 13. ed. Salvador, JusPodivm, 2018.

DUQUE, Marcelo Schenk. A questão da renúncia a direitos fundamentais. In:

Curso de Direitos Fundamentais: teoria e prática. São Paulo: RT, 2014. p. 106-120. FACHIN, Luiz Edson, SCHULMAN, Gabriel. Contratos, ordem econômica e princípios: um diálogo entre o direito civil e a Constituição 20 anos depois. In: SENADO FEDERAL: Estado e economia em vinte anos de mudança: sistema tributário e ordem econômica. Brasília, 2008, p. 349-379.

FARIA, Guilherme Henrique Lage. Negócios processuais no modelo constitucional de processo. Salvador: JusPodivm, 2016.

GRECO, Leonardo. Os atos de disposição processual - Primeiras reflexões. Revista Eletrônica de Direito processual. Out/Dez. 2007. Disponível em: <www.epublicacoes.uerj.br/index.php/redp/article/view/23657>. Acesso em 31/07/2018.

HACHEM, Daniel Wunder. Tutela administrativa efetiva dos direitos fundamentais sociais: por uma implementação espontânea, integral e igualitária. Tese (Doutorado em Direito), Curitiba: Universidade Federal do Paraná, 625f.

LEE, Patrick e GEORGE, Robert P., The Nature and Basis of Human Dignity, Ratio Juris, v. 21, no. 2, 2 June 2008.

MADUREIRA, Claudio, ZANETI JR., Hermes. Formalismo-valorativo e o novo processo civil. Revista de Processo, vol. 272/2017, on-line.

MARINONI, Luiz Guilherme. Da teoria da relação jurídica processual ao processo civil no Estado Constitucional. Revista dos Tribunais, v. 852, a. 2006, on-line.

MARTEL, Letícia de Campos Velho. Indisponibilidade dos direitos fundamentais: conceito lacônico, consequências duvidosas. Espaço Jurídico, Joaçaba, v. 11, n. 2, p. 334-373, jul./dez. 2010.

MENEZES, Joyceane Bezerra de; MULTEDO, Renata Vilela. A autonomia éticoexistencial do adolescente nas decisões sobre o próprio corpo e a heteronomia dos pais e do Estado no Brasil. A\&C - Revista de Direito Administrativo \& Constitucional, Belo Horizonte, a. 16, n. 63, p. 187-210, jan./mar. 2016. 
MELLO, Marcos Bernardes de. Teoria do fato jurídico: plano da existência. $13^{\mathrm{a}}$ ed. São Paulo: Saraiva, 2007.

MITIDIERO, Daniel. Bases para a construção de um processo civil cooperativo: o direito processual civil no marco teórico do formalismo-valorativo. Tese (Doutorado em Direito) - Universidade Federal do Rio Grande do Sul, Porto Alegre, 2007, $147 \mathrm{f}$.

NOBRE JÚNIOR, Edilson Pereira. Uma ideia de Constituição. Revista de Investigações Constitucionais, Curitiba, vol. 1, n. 1, p. 111-145, jan./abr. 2014

NOGUEIRA, Pedro Henrique. Negócios jurídicos processuais. Salvador: JusPodivm, 2016.

PIRES, Eduardo; ADOLFO, Luiz Gonzaga Silva. Autonomia privada e suas limitações legais: reflexo da incidência indireta dos direitos fundamentais. Revista de Estudos Constitucionais, Hermenêutica e Teoria do Direito, 7(2):176-187

PIRES, Luis Manuel Fonseca. Razões (e práticas) de Estado: os mal-estares entre a liberdade e a segurança jurídica. Revista de Investigações Constitucionais. Curitiba, v. 3, n. 3, set/dez. 2016, p. 167-189.

PUGLIESE, William Soares, ROSA, Viviane Lemes da. Normas fundamentais do novo Código de Processo Civil: considerações teóricas e hipóteses de aplicação pelo exame do contraditório. Revista Iberoamericana de derecho procesal, v. 3, a. 2016, on-line.

REDONDO, Bruno Garcia, Negócios processuais: necessidade de rompimento radical com o sistema do CPC/1973 para a adequada compreensão da inovação do CPC/2015, in DIDIER JÚNIOR, Fredie (org.). Coleção Grandes Temas do Novo CPC Negócios Processuais. $3^{\text {a }}$ ed. Salvador: JusPodivm, 2017, p. 391-401.

RUZYK, Carlos Eduardo Pianovski. Liberdade(s) e função: contribuição crítica para uma nova fundamentação da dimensão funcional do direito civil brasileiro. Tese (Doutorado em Direito), Universidade Federal do Paraná, Curitiba, 402f.

SAMPAIO, José Adércio Leite. Direitos fundamentais como trufas da maioria. Revista de Estudos Constitucionais, Hermenêutica e Teoria do Direito, 7(3):226-234, setembro-dezembro 2015. 
Revista Eletrônica de Direito Processual - REDP.

Rio de Janeiro. Ano 13. Volume 20. Número 3. Setembro a Dezembro de 2019

Periódico Quadrimestral da Pós-Graduação Stricto Sensu em Direito Processual da UERJ

Patrono: José Carlos Barbosa Moreira (in mem.). ISSN 1982-7636. pp. 451-481

www.redp.uerj.br

TALAMINI, Eduardo. Um processo para chamar de seu: nota sobre os negócios jurídicos processuais. Disponível em: <http://www.migalhas.com.br/dePeso/16,MI228734,61044-

$\mathrm{Um}+$ processo+pra+chamar+de+seu+nota+sobre+os+negocios+juridicos>. Acesso em 01/07/2018.

YARSHELL, Flávio Luiz. Convenção das partes em matéria processual: rumo a uma nova era? In: DIDIER JÚNIOR, Fredie (org.). Coleção Grandes Temas do Novo CPC Negócios Processuais. Salvador: JusPodivm, 2017, p. 75-93. 